\title{
Progress in Lowering the Number of Malnutrition Cases in Toddlers in Bone Regency, South Sulawesi
}

\author{
Zhery Mulyati ${ }^{1}$, Sudirman Nasir ${ }^{1}$, Ridwan Mochtar Thaha ${ }^{1}$ \\ Email: zhery.mulyati@yahoo.com \\ ${ }^{1}$ Health Promotion Section, Faculty of Public Health, Hasanuddin University \\ Makassar, Indonesia
}

\begin{abstract}
This study aims to analyze the factors, thus advancement Bone Regency in lowering malnutrition case in Toddler. This research uses qualitative research with a case study approach. Data were obtained by in-depth interviews and unstructured observations to 22 resource persons consisting of health workers, policy makers (stake holder), community leaders and cadres. Study results shows that all puskesmas carry out the PSG program, moreover the health worker perform the duties with positive attitude and good awareness. Availability of human resources for health care services for malnourished toddlers is 2-4 people, therefore at posyandu helped by 2-5 cadres. As well as support from stakeholder, and good participation from the community. However, there still a lack of knowledge from the community leaders, and cadres about PSG work program. Moreover, there is a shortfall for the availability of health worker in undernourished toddler, also the lack of awareness by some health workers towards teamwork. Inconclusion, the work program, attitude and health worker awareness, human resource availability, stake holder support, and community participation is proven to play a role in progress to reduce the number of cases of malnutrition at Bone Regency. Stakeholders are expected to make new adaptations or innovations to adjust to the situation during the Covid-19 pandemic, improve the teamwork system, add health workers who serve in undernourished toddlers, and increase more massive and active socialization about the PSG program.
\end{abstract}

Keywords: Malnourished, Toddler, Improvement

Received : September 17, 2021

Received in Revised: October 12, 2021

Accepted: October 23, 2021

\section{Introduction}

Malnutrition is the cause of almost half of all deaths in children under 5 years (UNICEF, Malnutrition, 2020). Globally, malnutrition in children is associated with high morbidity and mortality (Dicker et al, 2018; Olofin et al, 2013), so this problem is still a major concern in various countries, including Indonesia. The Indonesian government is committed to running a program so that there will be no more malnourished children by 2030 (Ministry of WUA and BPS, 2019), in line with one of the targets of the Sustainable Development Goals (SDG's) program which states that by 2030 end all forms of malnutrition (United Nations, 2015).

Globally, one in nine children is malnourished (UNICEF, 2018), and one in three children in the world are not growing well due to malnutrition. Good food and nutrition are not only the foundation of children's health and the development of society at large, but are also basic human rights of children (UNICEF, 2019). One in three children under five in Indonesia suffers from chronic malnutrition, and one in ten children experiences acute malnutrition (Bappenas and United Nations Children's Fund, 2017). The findings of the 2017 Indonesian National and Sub-National Disease Burden Analysis, malnutrition is one of the risk factors for DAYLs in

Copyright $\odot$ 2021, International Journal Papier Advance and Scientific Review, Under the license CC BY-SA 4.0

DOI: https://doi.org/10.47667/ijpasr.v2i2.116 
34 provinces in Indonesia (Balitbangkes RI, 2019). Nutrition has a profound effect on human health, and is closely linked to cognitive and social development, especially in early childhood. Malnutrition in the first 2 years of life, the main determinant of stunting, linear growth and obesity. Contributes to deficits in children's development and health, as well as productivity in adulthood (Black RE et al, 2013). This form of malnutrition can cause stunted children (short stature), overweight, and underweight. However, some children suffer from more than one form of malnutrition, such as stunting (short stature) and overweight, or stunting (short stature) and underweight (UNICEF/WHO/World Bank Group, 2019). Stunting or stunting is the most common form of child malnutrition (de Onis \& Branca F, 2016). Malnourished children are more likely to become short adults, tend to give birth to smaller babies, consequently lower educational achievement and ultimately have a lower economic status in adulthood (Lahariya, 2008).

The data shows a decrease in cases of malnutrition in children under five by 1.5 percent in 2019 when compared to 2018, but if you refer back to the existing data, malnutrition is still a very serious problem, therefore the problem of malnutrition must be addressed and carried out immediately. prevention. So far, various important strategies and national action plans have been prepared by the government as an effort to improve nutrition, as well as to address and prevent the problem of undernutrition from happening again. Indonesia is ranked 10th out of 44 countries in the Hunger and Nutrition Commitment Index (Hunger and Nutrition Commitment Index), this shows that the government is serious about eliminating malnutrition in Indonesia. The SUN (Scaling Up Nutrition) Movement is a global effort from various countries in order to strengthen commitments and action plans to accelerate nutrition improvement, especially handling nutrition from 1,000 days from pregnancy to children aged 2 years, and in Indonesia it is called the National Movement for the Acceleration of Nutrition Improvement in Framework for the First 1000 Days of Life (1000 HPK Movement), (Ministry of People's Welfare, Guidelines for Planning the 1000 HPK Movement Program, 2013). As well as monitoring nutritional status (PSG) which is one of the government programs and is implemented throughout Indonesia.

It is hoped that the appropriate strategy and program planning can overcome and prevent malnutrition in children in Indonesia. To achieve this, it is necessary to have roles and responsibilities, especially health workers, in providing health services that are right on target, and with actions that focus on planning existing programs to achieve progress. As well as cooperation from various cross-sectors, and community participation, it is also hoped that the government's seriousness in determining and supporting existing policies, so that the problem of malnutrition can be resolved.

The prevalence of malnutrition in Indonesia in 2018 was 17.7 percent (Riskesdas, 2018), and in 2019 it was 16.29 percent (SSGBI results report, 2020). South Sulawesi Province has 17.9 percent of cases of malnutrition. With 10 districts/cities that had the highest prevalence of malnutrition cases in 2017, namely Pangkep (30.9 percent), Gowa (28.8 percent), Takalar (26 percent), Jeneponto (24 percent), Pinrang (24.9 percent). percent). Then Maros (24.7 percent), Bone (23.8 percent), Luwu (23.6 percent), Wajo (23.5 percent), and Pare-pare (23.2 percent); (Monitoring of Nutritional Status, 2018). Bone Regency is in seventh place with cases of malnutrition in South Sulawesi, but based on the results of the annual report of the Bone Regency Health Office, the number of cases of malnutrition which was 6.33 percent in 2018, decreased in 2019 to 1.71 percent. This shows the success of Bone Regency in reducing the number of malnutrition cases, which is below the national malnutrition target in the 2019 Medium-Term Development Plan (RPJM) of 17 percent. Based on a preliminary study

Copyright () 2021, International Journal Papier Advance and Scientific Review, Under the license CC BY-SA 4.0

DOI: $\underline{\text { https://doi.org/10.47667/ijpasr.v2i2.116 }}$ 
conducted at the Bone Regency Health Office, it was stated that out of 5,3003 the number of toddlers in Bone Regency (2019), 11373 toddlers experienced nutritional problems (21.45 percent), and 907 toddlers with malnutrition (1.71 percent). There are 38 health centers in the Bone Regency, and all of them have data on children under five with cases of malnutrition. Although it was noted that all puskesmas in the working area of Bone Regency reported the presence of under-fives with malnutrition, almost all puskesmas or 89.48 percent showed a success rate in reducing the number of cases of malnutrition in children under five in the 20182019 period. So that researchers are interested in seeing what factors are the progress of Bone Regency in reducing the number of cases of malnutrition in children under five

\section{Methods}

This research was conducted at the Puskesmas in the working area of Bone Regency, South Sulawesi. Qualitative research method, with a case study approach, this research is retrospective in nature, namely evaluating or assessing an event that has occurred previously or in the past, to explain the results or conclusions in the future.

The sample was selected by purposive sampling based on predetermined criteria, which consisted of 20 informants from health workers, 22 stakeholders from the informants, 20 informants from the Integrated Service Post (POSYANDU) cadres, and 20 informants from community leaders.

Data collection techniques with in-depth interviews with informants. Interview guidelines as research references, camera documentation tools to photograph field conditions, observation sheets or field notes to record information, and/or mobile phones to record the interview process. The type of research analysis is content analysis, which is then interpreted and presented in the form of narratives and matrices. Content analysis is used to draw conclusions through efforts to find the characteristics of the message, and is carried out objectively and systematically (Bungin, 2015).

\section{Results and Discussion}

\section{Work Programs that Support Progress}

This study shows that the program that supports progress is the work program for monitoring nutritional status (PSG), with 23 performance indicators, and implemented in all puskesmas working areas of Bone Regencys.

"I know that the PSG program has 23 indicators, all of which are carried out with responsibility, and all must be achieved, carried out inside and outside the puskesmas building, such as posyandu” (R, 51 yrs, Kes Officer).

The knowledge of PSG stakeholders and health workers is very good, can explain 23 performance indicators, but the knowledge of community leaders (toma) and cadres is only little or less.

"I only know the activities, but it's not clear, I mean I don't know what they mean and how many there are. There are many activities carried out at the posyandu, not only weighing, but usually the puskesmas officers giving counseling, giving vitamin A, I also help in it. All activities carried out at the posyandu are going well" (RB, 25 yrs old, cadre).

The PSG program has standard operating procedures (SOP), and uses health operational assistance funds (BOK) for the implementation of activities. 
"We at the puskesmas, our fields are different, but we work according to the SOP, nothing is not. Each program has its own SOP” (H, 26 yrs old, Kes Officer).

Another supporting program is the nutrition-aware family program (KADARZI). The PSG program is considered very good and useful, because it is right on target and helps reduce malnutrition.

"If there is a KADARZI name here, a family aware of nutrition, this program is one of the Ministry of Health's strategic plans to reduce malnutrition, the goal is for families to be able to recognize nutritional problems of their family members, and be able to overcome them. In my opinion, it is suitable, because its performance is the same as the PSG program, and is supported by the government" (AZS, 36 years old, Stakeholder of PKM Ajangale).

\section{Health Staff Attitude}

This study shows that the attitude of health workers in carrying out their duties and responsibilities is responsible, such as visiting the homes of undernourished toddlers, being disciplined, being kind, loving children, friendly in communication, caring, attentive, diligent in work, happy to help. residents, and close to cadres, children and residents.

"They already know their respective job responsibilities, what their duties are, if the report is deposited before the 5th, it is already available. I noticed that in caring for patients, no one is indifferent, there is another one that I like the most, who is friendly" (S, 52 yrs, Stakeholder of PKM Watampone).

The duties and responsibilities of health workers are different, such as the person in charge, field coordinator, measuring $\mathrm{TB} / \mathrm{PB}$, administering vitamin $\mathrm{A}$, filling out registrations, conducting surveys for children under five, and assisted by cadres.

"I help, such as weighing and measuring body length, it is also customary to give milk, biscuits, iodized salt, and vitamins. Every month, they change their duties with other cadres" ( $\mathrm{S}, 41$ yrs old, cadre).

In teamwork, the attitude of health workers is good and responsible with their respective duties and obligations, coordinating and helping each other.

"Okay, all the ladies here are close, they usually go on home visits. I see that in the team everyone is good, working to help each other" (N, 59 yrs, Cadre).

Management of undernourished toddlers is registered first, weighs weight, measures head circumference and $\mathrm{PB} / \mathrm{TB}$, provides counseling to mothers about nutritious food consumed by toddlers, and next month it is recommended to come back to posyandu, given PMT, and monitored for growth and development.

"Monitored, see the progress, if there is a sign of a decrease in body weight, it means that you have entered a supervised toddler, so you need to give PMT" (FY, 25 yrs, Kes Officer).

\section{Health Officer Awareness}

This study shows that the awareness of health workers in carrying out their duties and obligations is very good and good, aware and understands their respective jobs.

"In carrying out their main duties and functions, they are very responsible, they know the responsibilities of their respective duties, they already know and 
understand. I noticed that when I went to the field, the preparation of tools and materials had been prepared beforehand, as well as the report before the 5th was already available" (S, 54 yrs old, Stakeholder of PKM Watampone).

Such as completing reports on time, carrying out home visits even during the Covid-19 pandemic, diligently working with cadres, if there is an activity / schedule for field trips, all tools and materials have been prepared before the activity, and diligently coming to the posyandu, but there are also officers who rarely come.

"It must be those who go out or not, maybe there are other things outside. But I always say, if you want to go out, just finish your office work first, then other things. If you are unable to coordinate with the team" (M, 54 years old, PKM Stakeholder Tana Batue).

In teamwork, in general the awareness of health workers is good, mutual respect, both with posyandu cadres and fellow health workers, helps each other, and is well coordinated. However, there are health workers whose awareness is lacking or still low, for example, when the team goes to the posyandu, they rarely participate or are absent.

"Members' awareness of teamwork is still lacking. It's normal when you go out on the field, there are friends who can't go down, so their duties are automatically taken over by other friends. Even though everyone has their own task in the team, that sometimes makes teamwork lacking, so it becomes chaotic” (F, $48 \mathrm{yrs,} \mathrm{Case}$ Officer).

\section{Availability of Human Resources for Health Workers}

This research shows that, the Puskesmas working area of Bone Regency has 21 to 31 posyandu, spread over 7 to 10 villages, and health workers are placed according to their competence.

"At the Ajangale health center, there are 91 health workers, with 31 posyandu in 10 villages. The main tasks and functions are adjusted to their competence. For services for undernourished toddlers there are 3 people assigned, all according to their competence. At the posyandu, the cadres are assisted" (AZS, 36 years old, PKM Ajangale Stakeholder).

There are 2 to 4 health workers who specialize in handling malnutrition in each puskesmas, but they are felt to be lacking or not enough.

"I don't know the total number of officers at the puskesmas, but specifically for undernourished children under five, there are 3 people from nutrition and 1 from midwife, so there are 4 in total. If you say it's enough, it's enough, but because the working area is wide, if you can add it" (F, 48 years old, Case Officer).

Each posyandu has a cadre of 2 to 5 people, there are no cadres on a special duty, all work to help puskesmas officers.

"There are 5 cadres. There is nothing for that only, because all the cadres here are done" (SA, 53 yrs old, cadre).

Training and technical guidance are provided by the Bone Regency Health Office, South Sulawesi Provincial Health Office, and the Ministry of Health for health workers according to their competence/field. 
"What is usually held is from the Health Office here, some from the Provincial Health Office" (RR, 55 yrs, Kes Officer).

Cadres were also given training and refresher by the puskesmas and the Bone Regency Health Office.

"Yes, training and refreshment are provided from the puskesmas, some are from the Bone Health Service" (NA, 40 years old, cadre).

\section{Stakeholder Support}

This study shows that stakeholders are very supportive and know about health services for undernourished children under five. The support is in the form of facilitating programs or activities, preparing budgets, providing direct directions, holding regular monthly meetings, direct service delivery, providing training and technical guidance, visits to posyandu, providing assistance in the form of providing materials and tools, and involving community leaders.

"I know and very supportive. This is very good and very precise, so if there is a case of malnutrition it can be immediately obtained and handled, so that stunting and malnutrition can be prevented, for that it is very necessary to provide services that specifically look at nutritional problems and can track them. The support provided, such as strengthening the capacity of human resources and budget" (EN, 44 yrs old, Stakeholder of Bone Regency Health Office).

Guidance and supervision are carried out in the form of routine monev, conducting crosssectoral meetings such as MMD, monthly reports, providing direct directions, routine supervision for program evaluation and supervision, monthly puskesmas internal meetings, and surprise inspections. Health workers are available in all puskesmas and posyandu, and health facilities in Bone Regency is quite complete, in the puskesmas there are inpatients, emergency rooms, standard laboratory examinations, except for X-rays and ultrasound which are carried out at the hospital. At the posyandu there are scales, meters, and Posyandu Kits as well as medicines, and vitamins are brought directly by health workers at the posyandu.

"In my opinion, the facilities at the puskesmas and posyandu are complete to support health services, if there are toddlers who need an X-ray or ultrasound, they are referred to the hospital" (R, 51 yrs old, Kes Officer).

Efforts are being made, namely by involving many OPDs, having a routine field trip schedule for program evaluation and supervision, direct direction, monitoring performance developments, coordinating and directing socialization to participate in training and meetings, briefing every morning, performance evaluation every month.

"We have a regular schedule for field visits, to evaluate and monitor stunting programs, including malnutrition. Of course, we coordinate with the Camat, and the head of the puskesmas, for the schedule because there are many and large subdistricts in Bone, so our team divides it." (KA, 52 years old, Stakeholder Health Office of Bone Regency).

\section{Community Participation}

This study shows that the community participates and supports the activities of the PSG program and services for undernourished children under five. The forms of participation are being a posyandu cadre, helping to distribute and preparing PMT, socializing and informing residents of posyandu activities, helping clean, organizing and preparing tools at the posyandu, 
providing a front yard for the posyandu to build, the house being used as a posyandu budgeting ADD for PMT procurement, mobilizing the community to diligently bring their toddlers to the posyandu, together with puskesmas officers to make home visits, pick up toddlers and their mothers at home if there is no transportation, bring their toddlers to posyandu, be involved in posyandu construction and cadre selection.

"I am very supportive. The local community supports posyandu activities. If you have a schedule, mothers with toddlers are always present. For posyandu cadres, as well as women from the neighborhood who are being trained, it becomes crowded when posyandu. I think the role of community participation is very helpful for officers at the puskesmas", (MHA, 72 years old, Toma).

The participation and support provided was very good, useful, very helpful, and strongly agreed with it because it had an influence on the progress and smoothness of activities at posyandu,

"I totally agree, because community participation is very helpful in posyandu", (FY, 25 yrs, Case Officer).

The PSG program is a program that is implemented in all puskesmas in the working area of Bone Regency, aiming to provide information on the magnitude of the problem of malnutrition. The PSG program has 23 work target indicators and must be achieved by all, with the main target being children aged 0-59 months. A program plays a very important role in helping to reduce nutritional problems such as malnutrition, a work program has an important role for success (Bullen PAB, 2011). The PSG program has standard operating procedures (SOPs), the aim of which is to make it easier for health workers to work and, to reduce errors and omissions at work (Hartati IP, 2014).

The PSG activity uses the Health Operational Assistance Fund (BOK), which is part of the non-physical special allocation fund (DAK) for the health sector to improve health services at the puskesmas, among others, to encourage healthy living, early detection, disease prevention and response efforts, and health activities. community health center level (Permenkes, 2021). Another supporting program is the nutrition-aware family program (KADARZI), with targets for toddlers aged 0-59 months, infants 0-6 months, under-fives 6-23 months from poor families, as well as pregnant, lactating, postpartum mothers, and mothers having children under two years old. Stakeholders and health workers have good knowledge of the PSG program, can explain 23 PSG indicators. However, the knowledge of community leaders and cadres is still low or lacking, they cannot explain the PSG performance indicators, but they know that the program is a work program at the puskesmas, and is carried out at the posyandu, such as weighing weight, measuring $\mathrm{PB} / \mathrm{TB}$ toddlers, PMT. Knowledge is a factor related to one's compliance (Erwin et al, 2017).

Attitude is a consistent response to an object or situation, which is positive or negative (Ahmadi, 1999, in Candra IW et al, 2017). A positive attitude given by health workers in carrying out their duties and obligations, namely being responsible, with integrity and good behavior, such as making reports on time, being friendly in answering questions, being disciplined with schedules, in good service and also being close to children, mothers and children. other residents, and attention if there are toddlers who do not attend the posyandu. Being responsible is the highest attitude (Irwan, 2017). A positive attitude affects the comfort of toddlers and parents, thus motivating them to come again to check their toddlers at the posyandu (Sambas, 2014). 
The duties and responsibilities of health workers are different, namely measuring TB/PB, as field coordinator, in charge, providing counseling and counseling, administering vitamin A, conducting surveys for children under five. In teamwork, the attitude of the health workers is good, such as mutual coordination and assistance with other team members, for example there are those who replace if someone is unable to enter, take turns providing counseling / counseling, measuring TB / PB, giving vitamin A. Cadres help such as recording register books , weighing weight, filling KMS, distributing PMT milk or biscuits. Every month the duties of cadres take turns / rotate tables, for example this month filling out KMS the next month weighing. The management of undernourished and malnourished children under five must receive preventive interventions for the management of malnutrition or be referred (PMK, 2020)

Awareness is a factor that influences the behavior and motivation of health workers in carrying out their duties and obligations. The better the knowledge possessed, the higher the level of awareness (Nemati et al., 2020). In carrying out their duties and obligations, the awareness of health workers is very good, namely knowing and understanding what has become their obligation, completing their work well, being responsible for their duties. Such as continuing to make home visits even during the Covid-19 Pandemic, if there are activities/field schedules that have previously prepared all the tools and materials to be used, reports are completed on time. Good health workers and cadres can increase visits by mothers who have toddlers to posyandu (Fitriyah et al, 2019). But if they are treated poorly, they tend to ignore the advice given and do not want to visit again (Pohan, 2007).

In teamwork, the awareness of health workers is good. As with cadres and fellow officers coordinate and help each other. However, in carrying out their duties and obligations as team members, there are still health workers whose awareness is still lacking or non-existent, such as not complying with the existing schedule of activities, namely those who do not attend or are absent during activities or work programs, so they rarely participate in team activities. to posyandu. And there are also those who are lazy to carry out their duties and obligations, hoping that their tasks are handed over to other team members present, while team members have their own duties, causing piling up tasks to one person, disrupting the tasks of other team members, also causing delays in activities. In teamwork, awareness is needed so that they can carry out and complete their respective duties properly and correctly. Because the job satisfaction of health workers is influenced by colleagues (Mubarak et al, 2016).

Availability of human resources, is the availability of health workers on duty and provide health services to children under five at the puskesmas. The availability of human resources for health workers is related to the use of health services, so that people want to take advantage of health services (Mujiati \& Yuniar, 2016). There are 2 to 4 health workers who specialize in handling malnutrition in each puskesmas. Even though they already exist, it is felt that they are still lacking or not enough, because of the wide and large work area that is the obligation and responsibility in their duties, so there is a need for additional health workers who are specialized in the service of undernourished children under five.

The lack of health workers has an impact on increasing workloads and hours, thus affecting the quality of health services so that they are not optimal (Hidana et al., 2018). And it can be a bad factor in the behavior of health workers in carrying out their duties (Indriani et al., 2018). Health workers are placed according to their competencies, because the quality of human resources is directly proportional to their competencies (Nawawi, 2012). There are 2 to 5 cadres in each posyandu, all assisting health workers, there are no cadres on special duty in the service 
of undernourished children under five. Cadres have an important role in motivating mothers of toddlers to visit posyandu (Subagyo et al., 2015). Training and technical guidance are provided to increase the knowledge and skills capacity of health workers by the Bone Regency Health Office, South Sulawesi Provincial Health Office, and the Ministry of Health. Improving service quality, one of which is by improving the quality and quality of human resources (Suparyanto, 2013). Cadres are also given training and reflection. Thus increasing confidence to share with the public about health (Salamah \& Sulistyani, 2018). And will increase their knowledge (Didah et al, 2019).

Stakeholders know and strongly support the health services for undernourished children under five, the support provided directly or indirectly. The support provided can affect the public or many groups (WHO 1984, in Notoatmodjo S 2012). The availability of health facilities in Bone Regency, such as puskesmas and posyandu, is quite complete, and health workers are also available. According to Dever (1984) who cited the Donabedian Utilization model, the skills and expertise of health workers are one of the factors that influence the community in the use of health services (Indriani et al., 2018). Fostering and supervising is a stakeholder task that is carried out regularly, and there have been many efforts made by stakeholders in supporting health services for undernourished children under five, so that it is hoped that it can provide better benefits and changes for the progress of Bone Regency in reducing cases of malnutrition in children under five.

Community participation is participating, or community involvement in assisting and supporting activities at the posyandu. This participation is very much needed because participation can support the success of the program (Mahardika et al., 2018). This participation includes being diligent in bringing their toddlers to the posyandu, namely mothers around the posyandu helping prepare and cooking PMT such as Manado porridge or green beans, cleaning and preparing posyandu equipment such as scales, rugs/carpets, and the Village Government preparing special ADD for PMT, namely purchase of 1 shelf egg/recipient family and making porridge for undernourished toddlers, which are included in the list of recipients, are made by the puskesmas from the findings of the Village Midwife and health workers in the field, and submitted to the Village Government. Health workers collaborate with cadres and community leaders, so that the community can be active in promotive and preventive activities (Chasanah, 2015).

Community participation is one of the posyandu cadres. Each posyandu has 2 to 5 cadres, helping such as taking register books, filling out KMS, distributing PMT milk or biscuits, weighing weight, and together with health workers going to the homes of residents with toddlers according to the list, distributing PMT and iodized salt. Cadres are selected by and from the local community, who are willing and able to voluntarily work together in various activities (Depkes RI, 2003). Community participation cannot be separated from the influence of community leaders (toma). Good toma support plays an important role in the utilization of health services by the community (Darmawan, 2016).

These participations are turning their house into a posyandu, being involved in meetings held by the local government, helping to call or picking up toddlers and their mothers at home if there is no transportation to the posyandu, directing and mobilizing residents to diligently bring their toddlers to the posyandu, providing land/home yards. personally to build a posyandu, together with residents and the Village Government to help establish a posyandu, and to socialize the activities/ schedule of posyandu announced through loudspeakers at the mosque, for example the exact schedule of the market day will be moved forward or postponed the day 
before, because if the posyandu coincides with that day there will be a lot of people Parents are active in the market so they cannot bring their toddlers to the posyandu. A person's behavior in society is much influenced by someone who is considered important, such as a toma, so that what Toma says and does tends to be used as an example and obeyed. The support provided can make the community actively participate in posyandu activities (Umayana \& Cahyati, 2015).

\section{Conclusion}

We conclude that the PSG work program, attitudes and awareness of health workers, availability of human resources for health workers, stakeholder support, and community participation are proven to have a relationship with the progress of Bone Regency in reducing the number of cases of malnutrition in children under five. It is hoped that stakeholders and health workers will make adaptations or innovations to adjust the situation during the Covid19 pandemic, so that health services, especially for undernourished children under five, can continue. Knowledge of community leaders and cadres about the PSG program is still lacking, so a more massive and active socialization is needed to increase knowledge. Health workers on special duty for health services for undernourished toddlers already exist, but they are felt to be lacking or not enough, so stakeholders are expected to add health workers. In teamwork, there are still team members who have low or less awareness to carry out their duties and obligations in the team, such as not attending or not participating in an activity, being lazy at work, and hoping that their tasks are done and completed by their teammates. So it is hoped that stakeholders can improve the teamwork system, for example by giving warnings or reprimands to the health workers.

\section{References}

Black RE., Victora CG., Walker SP., Bhutta ZA., Christian P., de Onis M., Ezzati M., McGregor SG., Katz J., Martorell R., \& Uauy R. (2013). Maternal and Child Undernutrition I; Maternal and Child Undernutrition and Overweight in Low-Income and Middle-Income Countries. The Lancet, 382: 427-51

Bullen P.A.B. (2011). The Positive Deviance/Hearth Approach to Reducing Child Malnutrition: Systematic Review. A European Journal Tripocal Medicine and Health. 16(11). 1354-1366. https://doi.org/10.1111/j.1365-3156.2011.02839.x.

Bungin B. (2015). Metodologi Penelitian Kualitatif: Aktualisasi Metodologis ke Arah Ragam Varian Kontemporer. Jakarta: PT.Raja Grafindo Persada.

Candra IW., Harini IGA., \& Sumitra IN. (2017). Psikologi Landasan Keilmuan Praktik Keperawatan Jiwa. Yogyakarta: CV Andi Offset.

Chasanah, S.U. (2015). Peran Petugas Kesehatan Masyarakat Dalam Upaya Penurunan Angka Kematian Ibu Pasca Mdgs 2015. Jurnal Kesehatan Masyarakat Andalas. 9(2). 73-79.

Darmawan, N. (2016). Faktor-Faktor Yang Mempengaruhi Perilaku Kunjungan Masyarakat Terhadap Pemanfaatan Pelayanan Posyandu Di Desa Pemecutan Kelod Kecamatan Denpasar Barat. Jurnal Dunia Kesehatan, 5(2), 76442.

De Onis M \& Branca F. (2016). Childhood Gizi Kurang: a Global Perspective. Maternal \& Child Nutrition. Department of Nutrition For Health and Development. Geneva: World Health Organization. 12 (Supp.I), pp. 12-26.

Depkes RI. (2003). Panduan Pelatihan Kader Posyandu Partisipasi. Jakarta; Bakti Husada. 
Dicker, D., Nguyen, G., Abate, D., Abate, K. H., Abay, S. M., Abbafati, C., ... \& Belay, S. A. (2018). Global, regional, and national age-sex-specific mortality and life expectancy, 1950-2017: a systematic analysis for the Global Burden of Disease Study 2017. The lancet, 392(10159), 1684-1735.

Didah, D., Madjid, T. H., Rachmadi, D., Husin, F., Setiawati, E. P., \& Sukandar, H. (2019). Pelatihan Posyandu Yang Telah Dimodifikasi Terhadap Peningkatan Pengetahuan, Peran Serta Masyarakat Dan Cakupan Jumlah Kunjungan Kia. JKM (Jurnal Kebidanan Malahayati), 5(1).

Erwin, R. R., Machmud, R., \& Utama, B. I. (2018). Hubungan Pengetahuan dan Sikap Ibu Hamil dengan Kepatuhan dalam Mengkonsumsi Tablet Besi di Wilayah Kerja Puskesmas Seberang Padang Tahun 2013. Jurnal Kesehatan Andalas, 6(3), 596-601.

Fitriyah, A., Purbowati, N., \& Follona, W. (2019). Faktor-Faktor yang Berhubungan Dengan Kunjungan Ibu Dengan Balita ke Posyandu. SEAJOM: The Southeast Asia Journal of Midwifery, 5(2), 79-83.

Hidana, R., Shaputra, R., \& Maryati, H. (2018). Faktor-Faktor yang Berhubungan dengan Pemanfaatan Pelayanan Kesehatan oleh Pasien Luar Wilayah di Puskesmas Tanah Sareal Kota Bogor Tahun 2018. Promotor, 1(2), 105-115.

Indriani, R. A., Zulfendri, Z., \& Utama, S. (2018). Pengaruh karakteristik organisasi terhadap pemanfaatan posbindu penyakit tidak menular di wilayah Puskesmas Helvetia. Berita Kedokteran Masyarakat, 34(9), 351-356.

Irwan. (2017). Etika dan Perilaku Kesehatan. Yogyakarta: Absolute Media.

Kementerian Kesehatan Badan Penelitian dan Pengembangan Kesehatan Republik Indonesia. (2019). Beban Ganda Penyakit Mengancam Indonesia. Retrieved 14 Juli 2020, from Info Litbangkes: https://www.litbang.kemkes.go.id/beban-ganda-penyakitmengancam-indonesia/.

Kementerian Kesejahteraan Rakyat. (2013). Pedoman Perencanaan Program Gerakan Nasional Percepatan Perbaikan Gizi dalam Rangka 1000 Hari Pertama Kehidupan (Gerakan 1000 HPK). Jakarta, DKI Jakarta, Republik Indonesia: Kementerani Koordinator bidang Kesejahteraan Rakyat Republik Indonesia.

Kementerian Pemberdayaan Perempuan dan Perlindungan Anak dengan Badan Pusat Statistik, Profil Anak Indonesia. (2019). Profil Anak Indonesia Tahun 2019. Jakarta. Kementerian Pemberdayaan Perempuan dan Perlindungan Anak (KPPPA).

Kementerian Perencanaan Pembangunan Nasional (Bappenas) dan United Nations Children's Fund (2017). Laporan Baseline SDG tentang Anak-Anak di Indonesia Jakarta: BAPPENAS dan UNICEF.

Kesehatan Republik Indonesia. (2018). Hasil Utama RISKESDA 2018. Jakarta. Kementerian Kesehatan Republik Indonesia.

Lahariya C. (2008). Maternal and Child Undernutrition: The Lancet Series and Indian Perspective. India: Indiana Pediatrics. Volume 45.

Mahardika, A. A., \& Fakhruddin, T. S. (2018). Partisipasi Masyarakat dalam Keberhasilan Program PAUD yang Terintregrasi dengan Posyandu. Jurnal Eksistensi Pendidikan Luar Sekolah (E-Plus), 3(2). 
Mubarak, S., Palutturi, S., Zulkifli, A., \& Nuru, H. (2016). Factors Affecting Work Satisfaction of the Village Midwives at Sidenreng Rappang Regency, South Sulawesi Province, Indonesia. International Journal of Health Sciences and Research (IJHSR), 6(1), 334340.

Mujiati, M., \& Yuniar, Y. (2016). Ketersediaan sumber daya manusia kesehatan pada fasilitas kesehatan tingkat pertama dalam era Jaminan Kesehatan Nasional di delapan Kabupaten-Kota di Indonesia. Media Penelitian dan Pengembangan Kesehatan, 26(4), 201-210.

Nawawi, M. (2012). Pengaruh motivasi dan kompetensi tenaga kesehatan terhadap kinerja pusat kesehatan masyarakat. None, 28(1), 7437.

Nemati, M., Ebrahimi, B., \& Nemati, F. (2020). Assessment of Iranian nurses' knowledge and anxiety toward COVID-19 during the current outbreak in Iran. Arch Clin Infect Dis, 15(COVID-19), e102848.

Notoatmodjo S. (2012). Promosi Kesehatan dan Perilaku Kesehatan. Jakarta: Rineka Cipta.

Olofin, I., McDonald, C. M., Ezzati, M., Flaxman, S., Black, R. E., Fawzi, W. W., ... \& Nutrition Impact Model Study (anthropometry cohort pooling). (2013). Associations of suboptimal growth with all-cause and cause-specific mortality in children under five years: a pooled analysis of ten prospective studies. PloS one, 8(5), e64636.

Peraturan Menteri Kesehatan Republik Indonesia. (2020). Nomor 2. 2 Januari. Tentang Standar Antropometri Anak. Jakarta: Negara Republik Indonesia.

Peraturan Menteri Kesehatan Republik Indonesia. (2021). Petunjuk Teknis Bantuan Operasional Kesehatan. Jakarta: Kementerian Kesehatan Republik Indonesia.

Pohan, I S. (2007). Jaminan Mutu Layanan Kesehatan. Jakarta: EGC.

Pusat Penelitian dan Pengembangan Upaya Kesehatan Masyarakat. Balitbangkes Kementerian Kesehatan Republik Indonesia. (2020). Studi status Gizi BALITA Terintergrasi SUSENAS 2019. Jakarta: Kementerian Kesehatan Republik Indonesia.

Salamah, N., \& Sulistyani, N. (2018). Pelatihan Peran Serta Kader Posyandu Dalam Pemberian Edukasi Kepada Masyarakat. Jurnal Pemberdayaan: Publikasi Hasil Pengabdian Kepada Masyarakat, 2(2), 249.

Sambas G. (2014). Faktor-Faktor yang Berhubungan dengan Kunjungan Ibu-Ibu Anak Balita ke Puskesmas Bojongherang Kabupaten Cianjur (Tesis). Depok: Universitas Indonesia.

Subagyo, W., \& Wahyuningsih, D. (2016). Peran kader dalam memotivasi ibu balita berkunjung ke posyandu. Jurnal Keperawatan Soedirman, 10(3), 158-166.

Umayana, H. T., \& Cahyati, W. H. (2015). Dukungan keluarga dan tokoh masyarakat terhadap keaktifan penduduk ke posbindu penyakit tidak menular. KEMAS: Jurnal Kesehatan Masyarakat, 11(1), 96-101.

UNICEF. (2018). Progress For Everychild in The SDG Era. Data And Analytics Section Division of Data. Research And Policy 3 UN Plaza. New York. 
UNICEF. (2020). Malnutrition. Unicef For Every Child. UNICEF Data: Monitoring the situation of children and women. Retriaved 2 Juli 2020. From https://data.unicef.org/topic/nutrition/malnutrition/\#more--1684.

United Nations Children's Fund (UNICEF), World Health Organization, International Bank for Reconstruction and Development/The World Bank. (2019). Levels and Trends in Child Malnutrition Estimates. Geneva. Key Findings of The 2019 Edition of The Joint Child Malnutrition Estimates. Geneva. World Health Organization. Licence CC BY NC, SA 3:0 IGO.

United Nations. (2015). Transforming Our World; The 2030 Agenda for Sustainable Development. A/RES/70/1 